\title{
Influence of Psychopathy and Cultic Disposition on Attitude toward Violence among Students of Tertiary Institutions in Ekiti State
}

\author{
Adebayo Sulaiman Olanrewaju ${ }^{1}$, Olawa Babatola Dominic ${ }^{2}$, Ogunleye Adedeji Julius ${ }^{3} \&$ Ayeye Funmilola ${ }^{3}$ \\ ${ }^{1}$ Faculty of the Social Sciences, Ekiti State University, Ado-Ekiti, Nigeria \\ ${ }^{2}$ Faculty of Humanities and Social Sciences, Federal University Oye-Ekiti, Nigeria \\ ${ }^{3}$ Department of Psychology, Faculty of the Social Sciences, Ekiti State University, Ado-Ekiti, Nigeria \\ Correspondence: Adebayo Sulaiman Olanrewaju, Faculty of the Social Sciences, Ekiti State University, \\ Ado-Ekiti, Nigeria. Tel: 234-803-386-5790. E-mail: lanryadd@yahoo.com
}

Received: August 3, 2013 Accepted: February 14, 2014 Online Published: August 22, 2014

doi:10.5539/ass.v10n17p258

URL: http://dx.doi.org/10.5539/ass.v10n17p258

\begin{abstract}
The study examined the influence of psychopathy and cultic disposition on attitudes toward violence among students of tertiary institutions in Ekiti State, Nigeria. One hundred and fifty six participants completed selfreport instruments comprising of the Levenson Self-Report Psychopathy Scale, Revised Attitudes toward Violence Scale and Disposition toward Cultism Questionnaire. The research participants were selected using the convenience sampling method. Responses from the survey research were analyzed using multiple regression and correlational analyses. Result of the study showed that both manifestations of psychopathy and disposition towards cultism independently and jointly predict attitudes toward violence. No significant relationship was found between psychopathy and cultic disposition. Results were discussed in line with previous literature and it was recommended that counselors and psychotherapists in tertiary institution settings should conduct holistic assessments of incoming and current students to diagnose for dispositions toward cultism and psychopathic traits so as to prevent occurrence of violent acts in the various academic communities of the country.
\end{abstract}

Keywords: cultic disposition, psychopathy, violence, tertiary institutions, students

\section{Introduction}

The issue of violence is as old as human existence. There is ubiquity of violence in the world, spanning from the east to the west, from north to south. Violence has become an issue that is inevitable in social interaction. In year 2000, it was estimated that about 1.6 million people worldwide lost their lives as a result of violence, a rate which is nearly 28.8 per 100000 (WHO, 2002). When violence becomes so intense, the consequence may result to the loss of lives and property of individuals involves, thereby leading to communal and societal breakdown.

Violence can be defined as the 'use of physical force to injure somebody or damage something' (Microsoft Encarta, 2009). The World Health Organization (1996) defines 'violence as the intentional use of physical force or power, threatened or actual, against oneself, another person, or against a group or community that either results in or has a high likelihood of resulting in injury, death, psychological harm, mal-development or deprivation' (cited in WHO, 2002, p. 4). These definitions reveal that violence can be typified by aggressiveness, destructiveness and callousness.

The violence unleashed by cult groups and student unions in the academic communities of the various tertiary institutions in Nigeria cannot be overemphasized. Violence in Nigerian higher institutions is not just a recent phenomenon. There is virtually no academic session where there is nonoccurrence of violence and students' unrest in most of the Nigerian public universities, polytechnics and colleges of education. There have been frequent occurrences of students' crises in Nigeria at varied levels of time phases (Ajibade, 2013). These crises could be noticed from the colonial era (1940-1960), to the immediate post independence and civil war era (1970-1986), and the economic crisis and adjustment (SAP) period (1986-1990s) (Onyenoru, 1996; Olamosu, 2000).

As defined by Ajayi, Haastrup and Osalusi, (2010), 'cultism can be seen as a ritual practice by a group of people whose membership, admission, policy and initiation formalities as well as their mode of operations are done in secret and kept secret with their activities having negative effects on both members and nonmembers alike' ( $p$. 
155). Since the 1990s, the operations of secret cults have become so horrorful and worrisome, marked by the murder arson, armed robbery and rape and lack of discipline (Oluwatobi \& Babatunde, 2010). Cultism is a social ill that has placed a deep sorrow on its victims whereby innocent students suffer humiliations and molestations from cultist (Maliki, 2009).

Periodically, the cruel and callous activities of cult groups on our universities and polytechnics are reported. One of such recent event was the killing of a 400 level Banking and Finance student of the Lagos State University, who is also a musician, Damilola Damochie on Feb. 282013 by suspected cultists at the institution's main gate (Vanguard News Paper, 2013). Violence erupted at Ekiti State University toward the end of year 2012 over the alleged killing of a cult member in which there was the damage of school properties that led to the closure of the University for a period of time. Apart from mayhem unleashed by cult groups, students have had cause to protest several policies formulated by the authorities of the various higher institutions through mob actions which often result into violence marked by destruction of school properties and loss of students' life. All these violent occurrences caused by students together with the industrial actions of workers' unions (ASUU, ASUP, SSANU, NASU etc) have led to frequent closure or disruption of academic calendar in the various tertiary institutions in the country.

The Nigerian government and security operatives have shown relentless efforts or devised several ways at nipping this menace at bud, but overall, all efforts have proved abortive. Through the media, individuals and groups have expressed their concern over the problem caused by the various cult crises. State and Federal authorities have made use of varied measures of tackling this menace by prosecuting and imprisoning cultists, rustication from tertiary institutions and publishing their names in national dailies among others (Arijesuyo \& Olusanya, 2010).

On the other hand, it has been empirically observed by psychologists that the influence of innate tendency can predispose individuals towards violence and destructiveness (Arijesuyo \& Olusanya, 2010). Violence can be seen as an overly complex issue caused by the interaction of various factors that are biological, social, cultural, economic and political (WHO, 2002). According to the ecological model of understanding violence, factors that could influence behavior or which increase the risk of committing or being a victim of violence is seen from four levels. The first level identifies biological and personal history factors that influence how individuals behave and increase their likelihood of becoming a victim or perpetrator of violence. Examples of factors that can be measured or traced include demographic characteristics (age, education, income), psychological or personality disorders, substance abuse, and a history of behaving aggressively or experiencing abuse (WHO, 2002).

From this model, it could be said that psychopathy, 'a personality disorder marked by antisocial thoughts and behaviors' (Microsoft Encarta, 2009) is capable of disposing students characterized by it into violent acts and aggression. Pyschopathy refer to a socially impaired individual who engages in unguarded and reckless behavior, of an antisocial or deviant kind (Hare, 1985; World Health Organisation, 1992; American Psychiatric Association, 1994). '...psychopathy can be understood as a constellation of personality features that generally includes remorselessness, callousness, deceitfulness, egocentricity, failure to form close emotional bonds, low anxiety proneness, superficial charm, and externalization of blame' (Lilienfeld, 1998, cited in Skeem, Poythress,Edens, Lilienfeld, \& Cale, 2003 p. 514 ).The strong nexus between psychopathy and offending can be characterized by interpersonal and affective cluster of traits like grandiosity, insensitivity, manipulation, lack of compassion, and lack of guilt or remorse (Hare, 1991). As noted in Snowden, Gray, Smith, Morris and Macculloch (2004), violence perpetrated by individuals high in psychopathy tends to be cold-blooded and instrumental (Cornell, Warren, Hawk, Stafford, Oram, \& Pine, 1996; Porter, Woodworth, Earle, Drugge, \& Boer, 2003, Woodworth \& Porter, 2002). Psychopaths show indifference to the violence committed rather than with grief, regret and guilt exhibited by many non-psychopathic offenders (Hare, 2001).

Thus, the preponderance of psychopathic traits among student population may better predict the initiation and extent of violence committed in the various higher institutions in the country rather than factors such as inadequate moral instructions, unconducive learning environment, peer group influence, parental and home background and the rest as highlighted by previous articles (e.g. Osakinle \& Falana, 2011; Ajayi, Haastrup, \& Osalusi, 2010; Amaele, 2013).

From the foregoing, it may be hypothesized that psychopathic traits and disposition toward cultism can independently and interactively predict attitude toward violence among tertiary students. Specifically, it is hypothesized that:

There will be a significant relationship between manifestation of psychopathic traits and attitude towards violence among tertiary institution students. 
There will be a significant relationship between cultic disposition and attitude toward violence among tertiary institution students.

There will be a significant independent and joint influence of manifestation of psychopathic traits and cultic disposition on attitude toward violence among tertiary institution students.

Hence, if students are assessed for psychopathic and cultic tendencies before and after enrolment, it may help authorities to have knowledge of, and follow up those that could initiate violence and possibly join cult groups on campuses, thereby reducing violent activities in our academic communities.

\section{Materials and Method}

In investigating the influence of psychopathy and cultic disposition on attitude toward violence, the following procedures were adopted.

\subsection{Research Participants}

A total of one hundred and fifty six (156) participants comprising of 73 males and 83 females with an age range of 16 to 30 were employed in this study. Participants were selected using convenience sampling from the students' population of Ekiti State University, Ado-Ekiti, Federal Polytechnic, Ado-Ekiti and College of Education, Ikere-Ekiti, Ekiti State.

\subsection{Research Design}

The study was an ex-post facto field study in which responses of research participants were collected using the questionnaire method. Thus, this study incorporates the correlation and regression designs. The correlatioanl design was adopted because the researchers are interested in investigating the relationship among variables of study. Regression design was adopted for the researcher to test the individual and combine influences of the independent variables on the dependent variable.

\subsection{Measures}

Three standardized psychological instruments were used in the study. They are:

I. The Levenson Self-Report Psychopathy Scale (LSRP) developed by Levenson, Kiehl, and Fitzpatrick (1995) to measure psychopathy. It is a 26-item inventory designed to measure primary psychopathy (assessing impersonal and affective features of psychopathy) and secondary psychopathy (assessing impulsivity and other anti-social behaviours). It is measured on a five point Likert-type scale ranging from strongly disagree (1) to strongly disagree (5). Levenson et al, (1995) found that primary and secondary psychopathy subscales correlate positively with each other $(\mathrm{r}=.40)$. The Cronbach alpha for both subscales are primary psychopathy, secondary psychopathy and global psychopathy are $.83, .71$ and .82 respectively (Levenson et al., 1995). Additionally, good test-retest reliability $(r=.83)$ was found when compared over a period of eight weeks (Lynam et al., 1999). Higher scores indicate increase psychopathic traits in the individual.

II. The Revised Attitudes toward Violence Scale (RAVS) was first published in the work Anderson, Benjamin, Wood and Bonacci (2006), though, originally designed by Velicer et al., (1989) as an extension of the Violence Scale developed by Bardis (1973). The scale consists of 39 items with four subscales (war in violence, corporal punishment, intimate violence and penal code violence) scored on a seven-point Likert-type scale, ranging from "Strongly Disagree" (1) to "Strongly Agree" (7). The reliability coefficients of the four factors are $.84, .80, .87, .91$ for war, penal code corporal and intimate violence respectively (Anderson, Benjamin, Wood, $\&$ Bonacci, 2006). Higher scores indicate a more positive attitude toward violence.

III. The Disposition toward Cultism Questionaire (DCQ) was developed for the purpose of this study to measure cultic disposition of participants. It is a 13 item questionnaire measured on five point Likert- type scale ranging from 'not at all characteristic of me (1)' to 'very characteristic of me (5).' Sample of items include "I like carrying out important activities in secrecy", "I can forcefully remove all stumbling blocks to the wheels of my progress". The Cronbach alpha coefficient of the scale obtained in the pilot study is 0.71 . Higher scores reflect more dispositions toward cultism. The items of the DCQ are shown in the appendix section.

\subsection{Procedure}

Two hundred copies of questionnaires containing the LSRP, RATVS and the DCQ together with biographic information eliciting items were given out to research participants to personally complete, having sought and obtained their consent to participate in the study. The completed copies of the questionnaire were later retrieved from respondents for analysis. Forty four copies (44) copies of the questionnaire were not properly completed, making one hundred and seventy (156) copies available for use in data analysis 


\section{Results}

Table 1. Means, standard deviations, and correlations among the study variables

\begin{tabular}{|c|c|c|c|c|c|c|c|c|c|c|}
\hline $\begin{array}{l}\text { Variable } \\
\mathrm{N}=156\end{array}$ & $\mathrm{M}(\mathrm{SD})$ & $\begin{array}{c}\text { Primary } \\
\text { Psycho- } \\
\text { pathy }\end{array}$ & $\begin{array}{c}\text { Secondary } \\
\text { Psycho- } \\
\text { pathy }\end{array}$ & $\begin{array}{l}\text { Psych- } \\
\text { opathy }\end{array}$ & $\begin{array}{c}\text { Cultic } \\
\text { Disposition }\end{array}$ & $\begin{array}{c}\text { War in } \\
\text { Violence }\end{array}$ & $\begin{array}{c}\text { Corporal } \\
\text { Punishment }\end{array}$ & $\begin{array}{l}\text { Penal } \\
\text { Code }\end{array}$ & $\begin{array}{l}\text { Intimate } \\
\text { Violence }\end{array}$ & $\begin{array}{c}\text { Att. } \\
\text { Toward } \\
\text { Violence }\end{array}$ \\
\hline $\begin{array}{c}\text { Primary Psycho } \\
\text { Pathy }\end{array}$ & $38(5.47)$ & - & $0.33 * *$ & $0.79 * *$ & 0.038 & $0.18^{*}$ & $0.33 * *$ & $0.33 * *$ & $0.26^{* *}$ & $0.38 * *$ \\
\hline $\begin{array}{c}\text { Secondary } \\
\text { Psycho } \\
\text { Pathy }\end{array}$ & $38.71(6.29)$ & & - & $0.84 * *$ & 0.077 & $0.31 * *$ & $0.27 * *$ & $0.39 * *$ & $0.40 * *$ & $0.44 * *$ \\
\hline $\begin{array}{l}\text { Psycho } \\
\text { Pathy }\end{array}$ & $76.71(9.61)$ & & & - & 0.072 & $0.30 * *$ & $0.36 * *$ & $0.44 * *$ & $0.41 * *$ & $0.48 * *$ \\
\hline $\begin{array}{c}\text { Cultic } \\
\text { Disposition }\end{array}$ & $39.45(12.29)$ & & & & - & $0.22 * *$ & 0.07 & 0.11 & $0.18^{*}$ & $0.20 *$ \\
\hline War in Violence & $37.56(8.67)$ & & & & & - & $0.46 * *$ & $0.54 * *$ & $0.49 * *$ & $0.82 * *$ \\
\hline $\begin{array}{c}\text { Corporal } \\
\text { Punishment }\end{array}$ & $25.85(6.72)$ & & & & & & - & $0.42 * *$ & $0.35 * *$ & $0.69 * *$ \\
\hline Penal Code & $21.09(5.27)$ & & & & & & & - & $0.60 * *$ & $0.78 * *$ \\
\hline $\begin{array}{l}\text { Intimate } \\
\text { Violence }\end{array}$ & $32.18(9.71)$ & & & & & & & & - & $0.82 * *$ \\
\hline $\begin{array}{c}\text { Att. Toward } \\
\text { Violence }\end{array}$ & $116.68(23.76)$ & & & & & & & & & - \\
\hline
\end{tabular}

Table 1 shows that primary psychopathy correlates positively with war in violence $\left(\mathrm{r}_{156}=0.18, \mathrm{p}<0.05\right)$, corporal punishment $\left(\mathrm{r}_{156}=0.33, \mathrm{p}<0.01\right)$, penal code $\left(\mathrm{r}_{156}=0.33, \mathrm{p}<0.01\right)$, intimate violence $\left(\mathrm{r}_{156}=0.26, \mathrm{p}<0.01\right)$ and the global attitude towards violence $\left(\mathrm{r}_{156}=0.38, \mathrm{p}<0.01\right)$.

Similarly, secondary psychopathy correlates positively with war in violence $\left(\mathrm{r}_{156}=0.31, \mathrm{p}<0.01\right)$, corporal punishment $\left(\mathrm{r}_{156}=0.27, \mathrm{p}<0.01\right)$, penal code $\left(\mathrm{r}_{156}=0.39, \mathrm{p}<0.01\right)$, intimate violence $\left(\mathrm{r}_{156}=0.40, \mathrm{p}<0.01\right)$ and the global attitude towards violence $\left(\mathrm{r}_{156}=0.44, \mathrm{p}<0.01\right)$.

Also, global psychopathy correlates with the global attitude towards violence $\left(\mathrm{r}_{156}=0.48, \mathrm{p}<0.01\right)$, war in violence $\left(\mathrm{r}_{156}=0.30, \mathrm{p}<0.01\right)$, corporal punishment $\left(\mathrm{r}_{156}=0.44, \mathrm{p}<0.01\right)$, penal code $\left(\mathrm{r}_{156}=0.41, \mathrm{p}<0.01\right)$ and intimate violence $\left(\mathrm{r}_{156}=0.48, \mathrm{p}<0.01\right)$.

Result also shows that there is no significant relationship between psychopathy and attitudes toward violence $\left(\mathrm{r}_{156}=0.072, \mathrm{p}>0.05\right)$.

Table 2. Summary of regression analysis showing the independent and joint influence of psychopathy and cultic disposition on attitude towards violence

\begin{tabular}{cccccccc}
\hline Variable & $\mathrm{B}$ & $\mathrm{t}$ & $\mathrm{Sig}$. & $\mathrm{R}$ & $\mathrm{R}$ Square & $\mathrm{F}$ & Sig. \\
\hline Psychopathy & 0.47 & 6.71 & $\mathrm{P}<0.01$ & 0.51 & 0.26 & 26.57 & $\mathrm{P}<0.01$ \\
Cultic Disposition & 0.16 & $\begin{array}{c}2.35 \\
\text { Dependent Variable: Attitudes toward violence }\end{array}$ & & & \\
\hline
\end{tabular}

Table 2 shows that there is a significant influence of psychopathy on attitudes towards violence $\left[\beta=0.47, \mathrm{t}_{154}=\right.$ $6.71, \mathrm{P}<0.01]$. Similarly, there is a significant influence of cultic disposition on attitudes toward violence $\left[\beta=0.16, \mathrm{t}_{154}=2.35, \mathrm{P}<0.5\right]$. Additionally, there is a significant joint influence of psychopathy and cultic disposition on attitudes towards violence [F (2) $153=26.57, \mathrm{P}<0.01]$.

\section{Discussions}

As shown in the results, psychopathy and it subscales (primary and secondary psychopathy) do have significant relationships with attitudes toward violence (war in violence, corporal punishment, penal code violence and intimate violence). So also does a significant relationship exist between cultic disposition and attitudes toward violence. All the subscales of violence attitudes significantly correlated with each other showing that the 
manifestation of one aspect of violence may predict the other. Additionally, there are strong significant independent and combined influences of psychopathy and cultic disposition on violent attitudes.

As a result of the anti-social nature of individuals with psychopathic traits, in addition to their lack of empathy, guilt and remorse in social interaction, they may be more disposed to initiating violent acts than those without the traits among tertiary institution students. The nature of this violence of psychopaths may be war-like (involving the use of arms and ammunitions), corporal (inflicting of pains to the body of others), penal (prescription of punishment to offenders) and dominating their partners by violence when in intimate relationship (Anderson et al., 2006).

The significance in the relationship between psychopathy and attitude towards violence is consistent with the outcome of the research conducted by Williams, Spidel, and Paulhus, (2005) where it is revealed that the violence that pervades psychopaths' lives is reflected in their intimate relationships. That is, psychopaths are likely to use violent ways to resolve conflicts when they are in intimate relationship with others. Moreover, not only are psychopaths more likely to engage in risky sexual behavior, they are more likely to use coercive strategies to obtain sex, including the intake of drugs or physical or verbal intimidation with their partner (Williams, Spidel, \& Paulhus, 2005).

In a similar direction to the present research, the studies reviewed by Skeem, Poythress, Edens, Lilienfeld, Cale, (2002) showed that psychopathic traits have been linked with more community violence, violent and nonviolent criminal recidivism than antisocial personality. Cornell et al. (1996) also found that offenders who had engaged at least one instrumental act of violence had higher scores on the Psychopathy Checklist-Revised (PCL-R \& Hare, 1991).

The relationship between disposition towards cultism and attitude toward violence found in this study explains the connection between cultism and violence witnessed in our various universities and polytechnics. It may be said that those students who are influenced to join cult groups and perpetrate violence are not at all times coerced by cult members but that; they themselves may have developed positive attitudes or disposition toward cultism. For example, a student who is forced may resist joining a cult group if he has negative attitudes toward becoming a member despite peer pressure, poverty, poor self esteem, societal decadence, search for security and other factors as enumerated by past studies. Invariably, cultism and violence begin from the dispositional and attitudinal levels where they sooner or later become full blown.

Several researchers have identified cultic activities with violent acts. Rotimi (2005) asserted that secret cult is not a new phenomenon in Africa, but what is new is the recent violence consistently associated with it. Today, the operations of cult groups in our tertiary institutions is accompanied with violence, maiming, killing and different types of anti-social activities (Ajayi, Haastrup \& Osalusi, 2010). Oluwatobi and Babatunde, (2010) have also asserted that cultism and gansterism are the causes of current upsurge of destructive and violent behaviors in Nigerian institutions of higher learning.

According to Opaluwah (2000) clashes among cult groups have led to an outburst of violence on campuses which resulted to causalities and death among students. In a research carried out among university students of the Nigeria middle belt zone, Smah (2001) noted that $15 \%$ of study sample reported to have either observed or narrated cult/gang motivated deaths on the campuses between one and two times in the years before. In 2006 alone, a minimum of one hundred students of tertiary institutions in Nigeria were killed in cult related incident (Yusuf, 2006). The violence perpetrated by secret cults is distinctively marked by killing, extortion, rape, maiming, stealing and all these have formed a lasting impressions on the mind of the average Nigerian (Raufu, 1997).

\section{Conclusion and Recommendation}

It is concluded in this study that both psychopathy and disposition toward cultism independently and jointly predict attitude toward violence among tertiary students in Ekiti State.

The result of this study has a lot of implications for tertiary institutions' policy makers and most especially psychologists and counselors within these institutions. This study also informs us that students who join cults are not just members because they were coerced to do so, but that, they themselves may develop positive attitudes toward cultism. Results could even explain the Boko Haram insurgencies that have turned the northern part of the country into volatilities and rampages. The members of this group (Boko Haram) are disposed to violence because of probable psychopathic and cultic related tendencies that characterize them.

It is therefore recommended that, there should be holistic assessments of incoming and current students of the various tertiary institutions in the country to diagnose for dispositions toward cultism and psychopathic traits. 
This process will help discover individuals who could initiate violence and possibly refer for management in due time to prevent future occurrence of violent behaviors in the academic environments and the country at large. With or without the inclusion of the two antecedent factors of violence discovered in this research, future studies should be focused toward investigating other factors that may predispose people into violent acts and most especially among individuals that have been convicted for societal violence in the past.

\section{References}

Ajayi, I. A., Haastrup, T. E., \& Osalusi, F. M. (2010). Menace of Cultism in Nigerian Tertiary Institutions: The Way Out. Anthropologist, 12(3), 155-160.

Ajibade, D. (2013). Students' crisis in Nigerian tertiary educational institutions: A review of the causes and management style. Khazar Journal of Humanities and Social Sciences, 16(1), 56-76.

Amaele, S. (2013). Menace of cultism in Nigeria tertiary institutions: challenges and way forward. International journal of education and management, 1(1), 32-41.

American Psychiatric Association. (1994). Diagnostic and statistical manual of mental disorders (4th ed.). Washington, DC: Author.

Arijesuyo, E. A., \& Olusanya, O. O. (2010). Theoretical Perspectives on Campus Cultism and Violence in Nigeria Universities: A Review and Conceptual Approach. International Journal of Psychological Studies, 3(1), 107-112.

Cornell, D. G., Warren, J., Hawk, G., Stafford, E., Oram, G., \& Pine, D. (1996). Psychopathy in Instrumental and Reactive Violent Offenders. Journal of Consulting and Clinical Psychology, 64, 783-790. http://dx.doi.org/ 10.1037/0022-006X.64.4.783

Hare, R. D. (1991). The Hare Psychopathy Checklist-Revised manual. Toronto: Multi-Health Systems.

Hare, R. (2001). The PCL-R assessment of psychopathy. Presentation at a training workshop on the Psychopathy Checklist-Revised and Psychopathy Checklist: Youth Version, Vancouver, British Columbia.

Hare, R. D. (1985). The Psychopathy Checklist. Unpublished manuscript, University of British Columbia, Vancouver: Canada.

Hare, R. D. (2001). Psychopathy and Risk for Recidivism and Violence. In N. S. Gray, J. Laing, \& L. Noaks, (Eds.), Crime, mental health and the politics of risk (pp. 27-47). London: Cavendish Press Ltd.

Hart, S. D., \& Dempster, R. J. (1997). Impulsivity and psychopathy. In C. D. Webster, \& M. A. Jackson (Eds.), Impulsivity: Theory, assessment and treatment (pp. 212-232). New York: Guilford.

Lilienfeld, S. (1998). Methodological advances and developments in the assessment of psychopathy. Behaviour Research and Therapy, 36, 99-125. http://dx.doi.org/10.1016/S0005-7967(97)10021-3

Maliki, A. E. (2009). Parental socio-economic status and attitude of towards cultism in Niger Delta University, Bayelsa State: Implication for counseling. Journal Human Ecology, 26(1), 65-69.

Microsoft Encarta. (2009). Psychopathy.

Olamosun, B. (2000). Crisis of education in Nigeria. Ibadan: Book Farm Publisher.

Oluwatobi, P., \& Babatunde,V. (2010). Cultism or gangsterism and its effect on moral development of learners in Nigerian tertiary Institutions. J. of Emerging Trends in Educational Research \& Policy Studies, 1(2), 61-64.

Onyenoru, I. P. (1996). Nature and management of students' conflict. Ibadan: Sociology Series No. 4, Department of Sociology, University of Ibadan.

Opaluwah, A. B. (2000). Cultism and Nigeria Campuses: The way out. Retrieved from http://www.ganji.com/

Oruwari, Y., \& Opuene, O. (2006).Youth in Urban Violence in Nigeria: A Case Study of Urban Gangs from Port Harcourt. Niger Delta Economics of Violence Working Papers 14. Retrieved from http://oldweb.geog. berkeley.edu/.../14-Oruwari...

Osakinle, E. O., \& Falana, B. A. (2011). Using counselling and behaviour modification to curb cultism in higher institutions of learning European. Journal of educational studies, 3(1), 45-51.

Pemede, O. (2001). Solving the problem of cultism through Christian Religious Education. Journal of Education Development (JONED). A publication of Nigerian Association of Educationists for National Development.

Porter, S. (1996). Without conscience or without active conscience? The etiology of psychopathy revisited. Aggression and Violent Behavior, 1, 179-189. http://dx.doi.org/10.1016/1359-1789(95)00010-0 
Porter, S., Woodworth, M., Earle, J., Drugge, J., \& Boer, D. (2003). In cold blood: Characteristics of sexual homicide committed by psychopathic and non-psychopathic offenders. Law and Human Behavior, 27, 459-70. http://dx.doi.org/10.1023/A:1025461421791

Raufu, S. A. (1997). Secret Cults in Nigerian Tertiary Institutions. Some ways out. LASU seminar series Aug. 3.

Rotimi. (2005). Violence in the Citadel: The Menace of Secret Cults in the Nigerian Universities. Nordic Journal of African Studies, 14(1), 79-98.

Skeema, J. L., Poythressb, N., Edensc, J. F., Lilienfeldd, S. O., \& Caled, E. M. (2003). Psychopathic personality or personalities? Exploring potential variants of psychopathy and their implications for risk assessment. Aggression and Violent Behavior, 8, 513-546. http://dx.doi.org/10.1016/S1359-1789(02)00098-8

Smah, S. O. (2001). Perceptions and Control of Secret Cult and Gang induced Difficulties for quality living and learning in Nigeria Universities. The case study of universities of the Middle Belt Zone. Centre for Development Studies. Retrieved from http://ahero.uwc.ac.Za/index

Snowden, R. J., Gray, N. S., Smith, J., Morris, M., Malcolm, J., \& Macculloch, M. J. (2004). Implicit affective associations to violence in psychopathic murderers. The Journal of Forensic Psychiatry \& Psychology, 15(4), 620-641. http://dx.doi.org/10.1080/14789940412331313377

Vanguard News Paper. (2013). Another LASU student killed by suspected cultists. Retrieved from http://www.vanguardngr.com/2013/03/another-lasu-student-killed-by-suspected-cultists/

Woodworth, M., \& Porter, S. (2002). In Cold Blood: Characteristics of Criminal Homicides as a Function of Psychopathy. J. of Abnormal Psychology, 111, 436-455. http://dx.doi.org/10.1037/0021-843X.111.3.436

World Health Organization. (1992). The ICD-10 Classification of Mental and Behavioural Disorders: Clinical descriptions and diagnostic guidelines. Geneva: WHO.

WHO. (1996). WHO Global Consultation on Violence and Health. Violence: A public health priority. Geneva: World Health Organization (document WHO/ EHA/SPI.POA.2).

World Health Organization. (2002). World report on violence and health: Summary. Geneva: WHO.

Yusuf, D. (2006). Cultism. Leadership. Retrieved from http://www.leadershipnigeria.com/

\section{Appendix}

Descriptive statistics for items of the DCQ

\begin{tabular}{lll}
\hline Items & mean & S.D \\
\hline I like carrying out important activities in secrecy. & 2.67 & 1.49 \\
I find societal rules and regulations burdensome & 2.45 & 1.42 \\
I can use arms and ammunitions to achieve my goals & 1.79 & 1.27 \\
I can take excessive alcohol and marijuana if I want to achieve a very hard task & 1.18 & 0.53 \\
I can extort people who I think have more than I have to meet my personal needs & 2.79 & 1.54 \\
I can forcefully remove all stumbling blocks to the wheels of my progress. & 2.97 & 1.63 \\
I don't see anything wrong in harming others who I perceive could cross my path & 2.09 & 1.42 \\
I don't condemn rapist for their actions because non rapist don't just have opportunities to & 1.36 & 0.74 \\
do so & & \\
I can do anything to befriend any boy or girl of my choice & 2.03 & 1.26 \\
I can organize an attack for any lecturer who failed me or disrupt my goals on campus & 2.55 & 1.58 \\
I like being feared by others around me & 2.48 & 1.46 \\
I can join groups or societies that can violently protest oppression & 2.21 & 1.47 \\
I always seek opportunities to command and control others. & 3.79 & 1.36 \\
\hline
\end{tabular}

\section{Copyrights}

Copyright for this article is retained by the author(s), with first publication rights granted to the journal.

This is an open-access article distributed under the terms and conditions of the Creative Commons Attribution license (http://creativecommons.org/licenses/by/3.0/). 